\title{
OS SONHOS FAMILIARES EM EL MATERIAL HUMANO (2009), DE RODRIGO REY ROSA
}

Rodrigo de Freitas Faqueri (IFSP)

Recebido em 22 jun 2019. Rodrigo de Freitas Faqueri é Doutor em Letras com Aprovado em 20 ago 2019. ênfase em Literatura Guatemalteca pela Universidade Presbiteriana Mackenzie, tendo como tema central a estética da violência na obra de Rodrigo Rey Rosa. Participou do PDSE ofertado pela CAPES na Universidad Nacional de Costa Rica. Mestre em Letras também pela Universidade Presbiteriana Mackenzie com ênfase nas Literaturas Brasileira e Argentina, tendo como temas principais os estudos em Mito, Reatualização Mítica, Dialogismo e Hipertextualidade (2013). Graduado em Licenciatura em Letras Habilitação Português/Espanhol pela mesma instituição em 2008. Atualmente é professor EBTT do IFSP - Campus Itaquaquecetuba. Possui experiência em estudos da área de Letras, com ênfase em Línguas Portuguesa e Espanhola e suas respectivas literaturas assim como em Estudos Culturais.

Resumo: Este artigo traz à tona um olhar sobre a literatura centro-americana a partir de um estudo realizado sobre o romance El Material Humano (2009), do escritor guatemalteco contemporâneo Rodrigo Rey Rosa. Como representante centroamericano, Rey Rosa apresenta as muitas faces de uma localidade imensamente rica para análises e estudos profundos, uma vez que seus textos possuem 
uma primorosa singularidade, construindo um projeto estético para ressignificar a identidade centroamericana e guatemalteca. Em El material humano (2009), encontra-se a história de uma personagem que consegue autorização para estudar os arquivos da Polícia Nacional Guatemalteca encontrados por acaso em um antigo hospital militar desativado. Entre sua busca pelos acontecimentos históricos que preenchem os arquivos da PNG e a sua vida, o protagonista se vê imerso em sonhos que lhe são extremamente familiares, mas que lhe causam um desconforto enorme exatamente por esta familiaridade e pela proximidade com a realidade em que ele está inserido. Assim, as indagações da personagem são sempre permeadas pelas suas experiências reais atreladas às situações consideradas do universo insólito.

Palavras-chave: Sonhos; Estranho familiar; Insólito; Rey Rosa.

Resumen: Este artículo evidencia una mirada sobre la literatura centroamericana a partir de un estudio realizado sobre la novela El Material Humano (2009), del escritor guatemalteco contemporáneo Rodrigo Rey Rosa. Como representante centroamericano, Rey Rosa presenta las muchas facetas de una localidad inmensamente rica para análisis y estudios, una vez que sus textos poseen una primorosa singularidad, construyendo un proyecto estético para resignificar la identidad centroamericana y guatemalteca. En El material humano (2009), se encuentra la historia de un personaje que logra tener autorización para estudiar los archivos de la Policía Nacional Guatemalteca encontrados por casualidad en un antiguo hospital militar desactivado. Entre su busca por los sucesos históricos y la verdad que se están presentes en los archivos de la PNG y en su vida, el protagonista se ve inmerso en sueños que le son extremadamente familiares, pero que le causan una incomodidad enorme exactamente por dicha familiaridad y la 
cercanía con la realidad en que él se encuentra. Siendo así, los cuestionamientos del personaje son siempre permeados por sus experiencias reales atrailladas a situaciones consideradas del universo insólito.

Palabras clave: Sueños; Raro familiar; Insólito; Rey Rosa.

\section{INTRODUÇÃO}

Nascido na Guatemala em 1958, Rodrigo Rey Rosa é um dos novos nomes da literatura hispano-americana contemporânea. Depois de abandonar a carreira de Medicina em seu país, residiu em Nova York e em Tanger. Em sua primeira viagem ao Marrocos, conheceu o escritor Paul Bowles, que foi o primeiro tradutor de seus livros para o inglês. Já escreveu romances, livros de relatos e contos, entre os quais se encontram El cuchillo del mendigo (1985), El agua quieta (1989), Cárcel de árboles (1991), El salvador de buques (1992), Lo que soñó Sebastián (1994), Que me maten si... (1996), El cojo bueno (1996), Ningún lugar sagrado (1998), La orilla africana (1999), Piedras encantadas (2001), El tren a Travancore (2002), Otro zoo (2005), Caballeriza (2006), Siempre juntos y otros cuentos (2008), El material humano (2009), Severina (2011), Los Sordos (2012), La cola del dragón (2014), Fábula Asiática (2017) e El País de Toó (2018). Suas obras, que já foram traduzidas a vários idiomas, representam a literatura centro-americana contemporânea.

Rey Rosa é um autor que traz uma perspectiva renovadora para a literatura de seu país e proporciona uma inovação no fazer literário no continente. Para Cano (2012), em Cárcel de árboles, por exemplo, tem-se uma exploração lúcida de uma modalidade escritural que lhe proporciona uma abertura para o desenvolvimento de questionamentos no âmbito ético e 
também estético. $\mathrm{O}$ escritor guatemalteco busca uma detalhada profundidade autorreflexiva sobre diferentes temáticas e questionamentos presentes em suas obras:

En esta novela, Rey Rosa ejecuta una minuciosa cavilación autorreflexiva sobre los diversos rasgos que permiten situar una obra en el campo de la CF, a la vez que establece un diálogo intertextual con tres renombrados exponentes de esta tradición escritural en el continente hispanoamericano: Rubén Darío, Jorge Luis Borges y Adolfo Bioy Casares. (CANO, 2012, p.2) ${ }^{1}$

Ao relacionar a escrita de Rey Rosa com a destes três tradicionais escritores hispano-americanos, Cano busca evidenciar que a escrita do guatemalteco rompe com as estruturas anteriores e busca seu lugar como representante exponencial de sua geração contemporânea, trazendo uma nova configuração para a literatura atual guatemalteca ou centro-americana assim como tais escritores buscaram fazer em suas respectivas gerações.

Em suas narrativas, além do enigma presente, trabalha-se a temática da violência que transcende a realidade e se magnetiza na ficção focada na circunstância da Guatemala em pós-guerra e o absurdo narrado em uma prosa de grau zero que traduz a desesperança filosófica em seus contos e também em seus romances (GUTIÉRREZ, 2008).

Para esta análise, foi escolhido o romance El material humano (2009), no qual, além da violência claramente exposta, pode-se os diversos traços que permitem situar uma obra no campo da ficção científica, uma vez que estabelece um diálogo intertextual com três renomados expoentes desta tradição escritural no continente hispano-americano: Rubén Darío, Jorge Luis Borges e Adolfo Bioy Casares. 
perceber a construção do narrador protagonista, que propõe a eliminação da fronteira entre a realidade e a ficção e habilitase, então, a possibilidade de esses dois universos se misturarem a ponto de não se poder distingui-los claramente por conta do absurdo existente no cotidiano da personagem protagonista e de suas experiências. As imagens que são construídas na narrativa se contrapõem entre a calma e a agressividade, quase sempre a primeira sendo transgredida pela agressividade direta ou indireta dos fatos ocorridos que refletem a violência pertencente ao texto.

Além disso, a violência também permite a construção do insólito na narrativa a partir dos sonhos tidos pelo protagonista e pelo absurdo narrado, por exemplo, nos motivos de fichamento de guatemaltecos nos arquivos policiais ou dos acontecimentos narrados em determinados contos como "La entrega", "El camino se dobla", "El monastério", "La señal, La llave perdida", "La razón”, "El agua quieta”, todos compilados no livro 1986. Cuentos completos (2014).

Nestas narrativas apontadas, a perspectiva fantástica se apresenta e permanece para proporcionar uma reflexão sobre a pluralidade de sentidos ocasionada pelas construções imagéticas do insólito não só com suas temáticas, mas também em suas estruturas narrativas complexas. Com o desenvolvimento das tramas, o real e o ficcional mesclam-se nas ações e indagações dos protagonistas fazendo com que a aproximação com o real seja posta em xeque pelo absurdo que se pode encontrar no cotidiano descrito nos enredos.

Nesta perspectiva, estrutura-se a narrativa analisada neste artigo: implantando seus alicerces com elementos considerados do universo 
onírico no qual os parâmetros de realidade e racionalidade não são os mesmos considerados pelos indicadores da verossimilhança e da lógica real. Constrói-se uma suposta estabilidade que poderá ser modificada e indagada a qualquer momento não pelo crivo do leitor simplesmente, mas, principalmente, pelo direcionamento dado pelo narrador à história contada.

\section{EL MATERIAL HUMANO (2009): UMA ESTRANHA FAMILIARIDADE NA (IR)REALIDADE HISTÓRICA}

Em El Material Humano (2009), Rey Rosa traz indícios de que a narrativa será autobiográfica pelas semelhanças existentes entre a vida do próprio autor e do narrador-protagonista. Entretanto, com o desenvolvimento da trama, o real e o ficcional mesclamse nas ações e indagações do protagonista fazendo com que a aproximação com o real seja posta em xeque pelo absurdo que se pode encontrar no cotidiano descrito no enredo.

Dividida em quatro cadernetas e cinco cadernos de anotações, a narrativa se produz, aparentemente, como um relato das experiências e das descobertas do narrador-protagonista no Arquivo do antigo Palácio da Polícia. Entretanto, os relatos sobre os arquivos se misturam com experiências do cotidiano vividas além dos papéis achados e do lugar que os guarda.

Na obra analisada, o narrador-protagonista traz algumas citações de escritores conhecidos como Kafka, Borges, Voltaire e Albert Camus, assim como as suas experiências pessoais como investigador para analisar um arquivo policial. Ao citar esses autores, o real e o ficcional também se emaranharam na narrativa a partir dessa perspectiva, pois o conhecimento do real se 
torna possível por meio dos olhares oriundos da ficção e/ou dos pensamentos filosóficos.

Nesta narrativa, ao construir seu narrador-protagonista e a história que o involucra, Rey Rosa faz com que se elimine a fronteira entre a realidade e a ficção. Um escritor, personagem principal da trama, mas que não traz um nome próprio declarado, apresenta semelhanças com o próprio autor: ambos recebem a permissão de estudar os arquivos da Polícia Nacional Guatemalteca encontrados no porão de um hospital militar em 2005.

Com relação à estruturação dos enigmas que aparecem na narrativa por conta dos acontecimentos curiosos em torno dos arquivos policiais pesquisados, o narrador propõe pensar no jardim borgeano dos senderos que se bifurcan ${ }^{2}$ e no detetive que imagina seu trabalho como a movimentação de um labirinto infinito. As dúvidas que envolvem o narrador e inclusive seus medos diante de telefonemas no meio da noite e sonhos confusos não são solucionados, mas multiplicados por variantes presentes no enredo. O próprio narrador não aclara seus questionamentos e chega a propor o seguinte:

Inesperadamente me pregunto qué clase de Minotauro puede esconderse en un laberinto como éste. Tal vez sea un rasgo de pensamiento hereditario creer que todo laberinto tiene su Minotauro. Si éste no lo tuviera, yo podría caer en la tentación de inventarlo. (REY ROSA, 2009, p.56) Luis Borges que possui este título.

3 Inesperadamente me pergunto que tipo de Minotauro pode se esconder num labirinto como este. Talvez seja um traço de pensamento hereditário acreditar que todo labirinto tem seu Minotauro. Se este não o tivesse, eu poderia cair na tentação de inventá-lo. (REY ROSA, 2011, p.58). 
Depois de um bom período afastado, antes de ser teoricamente liberado de sua suspensão para acessar o Arquivo, o protagonista relata o desejo de retornar àquele ambiente com personagens que coincidem com os pertencentes ao mundo de Kafka, onde as personagens principais correntemente enfrentam um campo complexo, que se sustenta com preceitos incógnitos e que quase nunca chegam a compreender efetivamente; um universo regido pela inverossimilhança e pela irrealidade que desestabiliza a lógica humana mais simples e natural, provocando pânico naqueles que não imergem em sua totalidade:

Sin duda, quiero volver al Archivo. Quiero ver de nuevo el lugar, con la tropa de investigadores que me hacen pensar en personajes de Kafka, con sus ropas estrafalarias, sus piercings y tatuajes debajo de las gabachas de uniforme color ocre con insignias verde esperanza donde dice <<Proyecto de Recuperación del Archivo»>; [...] Todos, en cierta manera, archivan y registran documentos por o contra su propio interés. Con anticipación, y quizás a veces con temor también. Nadie sabe, como dicen, para quién trabaja - ni menos aún para quién trabajó. (REY ROSA, 2009, p.85-86) ${ }^{4}$

Neste trecho acima, consegue-se perceber os contrapontos de uma estrutura linguística arquitetada na (ou pela) violência: o protagonista deseja voltar ao Arquivo para ver a tropa de pesquisadores que ali trabalham. Com o termo em destaque,

Sem dúvida, quero voltar ao Arquivo. Quero ver novamente o lugar, com a tropa de pesquisadores que me lembram personagens de Kafka, com suas roupas espalhafatosas, seus piercings e tatuagens sob os aventais dos uniformes ocre com insígnias verde-esperança, em que se lê: "Projeto de Recuperação do Arquivo". [...] Todos, de certa maneira, arquivam e inspecionam documentos por ou contra seu próprio interesse. Com premeditação, e às vezes talvez com medo, também. Ninguém sabe, como dizem, para quem trabalha - muito menos para quem trabalhou. (REY ROSA, 2011, p.90) 
remete-se à ideia de um termo militar, um exército preparado, com seus uniformes ocres, marchando sob as ordens expressas para cumprir sua missão. Contrapondo essa imagem, têm-se as roupas espalhafatosas, piercings e tatuagens que não condizem com o ambiente militar, mas que ajudam a construir esse cenário surreal da narrativa. Além disso, os uniformes ocres possuem um emblema de cor específica: verde-esperança o que também reforça o caráter contrastante da imagem mostrada.

Dessa forma, nas mesmas personagens, tem-se a perspectiva da agressividade militar, que remonta à história violenta guatemalteca com a esperança refletida na coloração do distintivo e nas características dos apetrechos utilizados por esses diversos pesquisadores que aludem aos anseios de parte da população atual em aclarar a verdade sobre os atos praticados pelo Estado. Complementando o enigma da narrativa e reforçando a ideia de insegurança dentro do relato, tem-se a última linha do trecho em que ninguém afirma para quem trabalha ou para quem trabalhou. Dessa maneira, não se sabe se são agentes do Governo infiltrados ou pesquisadores querendo trazer à tona a verdade, ou mesmo (ex) guerrilheiros buscando informações oficiais ou algo mais.

A verdade é que não se sabe quem são realmente as pessoas que trabalham no Arquivo e quais seus propósitos ali. Cria-se uma atmosfera nublada a partir de elementos que poderiam ser simplesmente classificados como comuns, porém são mostrados ao leitor com características peculiares que propiciam a dúvida ao se tentar confiar em suas proposições e atitudes. 
É interessante também ressaltar que essas personagens, aparentemente pertencentes ao universo kafkiano de acordo com o narrador, fazem parte da realidade guatemalteca. São personagens fictícias (ou não) que complementam o cenário real e histórico da Guatemala atual, vagando pelos dados dos relatórios policiais, convivendo com a barbárie escrita em milhares de folhas e praticada no cotidiano do país durante todo o século XX. O emaranhamento do real com o ficcional se desdobra dentro das variáveis apresentadas na narrativa causando dúvida, estranhamento e inquietação no leitor.

No quinto caderno, de capa espanhola, o protagonista inicia seu relato afirmando ter descoberto seu apelido dado pelos trabalhadores do Arquivo a ele. Os arquivistas o chamam de Matrix. No filme de 1999, estrelado por Keanu Reeves, um jovem programador agoniza por conta de pesadelos obscuros após ser conectado por cabos a um imenso sistema de computadores e, à proporção que seus sonhos se repetem, começa a duvidar da realidade em que está inserido ${ }^{5}$.

Na obra de Rey Rosa, o apelido dado à personagem principal reflete o enredo narrado nos cadernos e cadernetas apresentados, pois tem-se uma realidade à qual se custa dar credibilidade pelas constantes evidências da violência ao ser humano e à convivência pacífica que poderia existir em uma sociedade. AMatrix de Rey Rosa é o Arquivo de La Isla e toda a narrativa envolta nele é iniciada a partir dos fatos descobertos ali. É a essência de El material humano percebida pelas diversas realidades possíveis ao se conectar

5

O programador logo descobre, através de outras personagens, que a realidade em que vivia era na verdade uma simulação interativa neural, chamada Matrix, e que o mundo vivia uma era pós-apocalíptica dominada por máquinas com autoconsciência, sustentadas pela bioeletricidade gerada pelos corpos humanos ligados à Matrix. 
aos seus caminhos levantados. Descrevendo mais uma vez esse ambiente onírico, o narrador faz o seguinte relato após divulgar seu apelido de origem cinematográfica:

Como en una parábola de Kafka, para ingresar en el polvoriento laberinto que es el Archivo de La Isla, bastó con pedir permiso. Dentro, cuarto oscuro y húmedo tras cuarto oscuro y húmedo, todos llenos de papeles con su pátina de excrementos de ratas y murciélagos; y, pululando por ahí, más de un centenar de héroes anónimos, uniformados con gabachas, protegidos con mascarillas y guantes de látex- y vigilados por policías, por círculos concéntricos de policías, por policías integrantes de las mismas fuerzas represivas cuyos crímenes los archivistas investigan. (REY ROSA, 2009, p.143) ${ }^{6}$

Neste trecho, a construção da narrativa questiona a veracidade da realidade frente aos absurdos descritos. $\mathrm{O}$ ambiente, quase uma metáfora kafkiana, abriga defensores da verdade e pesquisadores de boa-fé, que são vigiados por perto por policiais que poderiam ser potencialmente acusados pelas informações encontradas naqueles documentos. A tensão provocada pela presença dos policiais em grande quantidade monitorando as ações dos arquivistas é aumentada pelo ambiente que os acomoda: um labirinto escuro e úmido cheio de papéis condenatórios das ações abusivas e violentas da Polícia Nacional, cobertos por dejetos de ratos e morcegos, como se essa informação adicional reforçasse a ideia repulsiva das

Como numa parábola de Kafka, para entrar no empoeirado labirinto que é o Arquivo de La Isla, foi só pedir permissão. Lá dentro, quarto escuro e úmido seguido de outro quarto escuro e úmido, todos cheios de papéis com sua pátina de excrementos de ratos e morcegos; e, pululando por ali, mais de uma centena de heróis anônimos, uniformizados com aventais, protegidos por máscaras e luvas de borracha - e vigiados por policiais, por círculos concêntricos de policiais, por policiais integrantes das mesmas forças repressivas cujos crimes os arquivistas pesquisam. (REY ROSA, 2011, p.151). 
atitudes governamentais executadas por seus agentes contidas naqueles papéis, engrossando o caráter sujo e pútrido da realidade guatemalteca. Curiosamente, para entrar neste espaço foi somente necessário o protagonista solicitar uma permissão. Para o leitor, a premissa também é válida: basta ler as cadernetas e cadernos apresentados pelo narrador para entrar neste universo insólito. Nada necessariamente explícito, mas, de todos os modos, aterrorizante.

Esse universo, ora surreal ora real, mas fora dos padrões considerados em certo ponto aceitáveis pela realidade é o que ambienta a narrativa apresentada por Rey Rosa. Tal território se torna paradoxal quando se tem a consciência de que as referências postas para a construção desse ambiente partem da realidade guatemalteca: os relatos feitos pelo protagonista, os cenários descritos, os trechos de obras e recortes de notícias de jornais, as ruas e cidades percorridas remontam a Guatemala atual vista a partir de uma perspectiva que questiona a veracidade dos acontecimentos por causa do absurdo presente nos fatos contados. Envolvendo todos esses relatos e cercando as personagens da narrativa está a violência, seja clara e atroz, como as mortes relatadas, seja mais sutil, porém não menos assustadora, como as ameaças e os sonhos do protagonista.

Os relatos de seus sonhos começam quando o protagonista viaja para Oaxaca, México. Depois de uma tarde bebendo mescal em terras mexicanas, à noite uma catarata de visões e lembranças ${ }^{7}$ percorrem sua mente. Com autorização para retornar ao Arquivo somente após uma conversa pessoalmente com o chefe, os pesadelos do protagonista começam a ser relatados. 
Os três primeiros pesadelos do narrador possuem alguns traços em comum. Seus pais aparecem dentro dos relatos ou então suas aflições inconscientes se passam na casa de seus familiares. No primeiro, estando na casa de seus pais com B+, sua namorada, o narrador começa a ouvir risadas que classifica como tipicamente de "fantasmas". O que o assusta, porém, não são as risadas, mas a imagem que vê depois disso:

Una pesadilla inolvidable, anoche que volvía de Oaxaca. [...] No fue un sueño violento, fue lo que se diría un auténtico sueño de fantasmas. Estábamos $\mathrm{B}+\mathrm{y}$ yo en casa de mis padres, en el dormitorio de mis padres, de pie junto a la puerta vidriera que da al jardín. Por los tonos y brillos verdes de la grama y el verde casi negro de las hojas de los árboles (temblorosas en el mismo sueño), yo sabía que el día declinaba. Hubo un ruido extraño en el fondo de la casa, hacia el corredor que lleva a la sala. Al ponerme a escuchar, oí unas risas demenciales que parecían venir de la cocina. B+ estaba muy asustada. Preguntó: 《<¿Qué fue eso?»> <<Fantasmas - le dije -, ésa tiene que ser de un fantasma, o de alguien que nos quiere espantar.>

Voy al corredor, donde, de pronto, se ha hecho de noche, está muy oscuro. Alargo el brazo - creo que hice también en la cama, mientras dormía - para encender a luz. [...]

Al encender la luz vi a mi padre que entraba desde el balcón. Parecía cansado, estaba mucho más delgado de lo que es en realidad. Traía bajo el brazo algo que pensé que era una botella de cerveza, cerveza oscura. Pienso: <<Entonces, no era él >>. (Mi padre, que yo recuerde, nunca bebió cerveza oscura). Ahora las risas se oyen más débilmente. El hombre de la cerveza, que puede 
ser mi padre, o no, impasible; como si no hubiera oído nada extraño. Entra en un cuarto y cierra la puerta suavemente. Oigo el clic. $Y$ entonces sí, despierto aterrado, sudando, con frío por el contacto de la pijama mojada con la piel. [...] (REY ROSA, 2009, p.92-93) ${ }^{8}$

Neste trecho, a imagem do pai atrelada à presença de um fantasma descortina uma imagem, que para o protagonista remonta o ambiente familiar, deslocada, entretanto, de sua referência inicial. A ideia do semblante paterno, que é no mínimo conhecida e pode ser em certas ocasiões aconchegante e tranquilizadora, é desmontada pela figura estranha que surge na sacada da casa. Com características semelhantes ao pai do protagonista, mas com detalhes que põem à prova a autenticidade do vulto visto, tem-se o conceito do íntimo, do pessoal, do familiar que se desconfigura a partir de uma situação nova.

De acordo com Freud (1919), essa imagem causadora da inquietude do protagonista dentro de um ambiente familiar pode ser

Um pesadelo inesquecível, ontem à noite, na volta de Oaxaca. [...] Não foi um sonho violento, foi, digamos, um autêntico pesadelo com fantasmas. B+ e eu estávamos na casa de meus pais, no quarto deles, em pé junto da porta envidraçada que dá para o jardim. Pelos tons e brilhos verdes da grama e do verde quase negro das folhas das árvores (trêmulas no próprio sonho), eu sabia que o dia estava caindo. Veio um barulho estranho dos fundos da casa, pelo corredor que leva à sala. Fiquei atento e ouvi risadas enlouquecidas que pareciam vir da cozinha. $\mathrm{B}+$ estava muito assustada. Perguntou: $-\mathrm{O}$ que foi isso? - Fantasmas - disse eu -, essa risada só pode ser de um fantasma, ou de alguém que quer nos assustar.

Fui até o corredor, onde, repentinamente, fez-se noite. Estava muito escuro. Estiquei o braço - acho que fiz isso também na cama, enquanto dormia - para acender a luz. [...] Ao acender a luz, vi meu pai entrando pela sacada. Parecia cansado, estava muito mais magro do que de fato é. Trazia debaixo do braço algo que pensei ser uma garrafa de cerveja, cerveja preta. Penso: "Então, não era ele". (Meu pai, que eu me lembre, nunca bebeu cerveja preta). Agora, o som das risadas se ouve fracamente. O homem da cerveja, que pode ser meu pai ou não, está impassível, como se não tivesse ouvido nada estranho. Entra num quarto e fecha a porta suavemente. Escuto o clique. E aí sim, acordo apavorado, suando, com frio pelo contato do pijama molhado com a pele. (REY ROSA, 2011, pp.97-98). 
classificada como unheimlich ${ }^{9}$, ou aquilo que não é essencialmente misterioso, nem totalmente obscuro, mas que causa estranheza e desconforto exatamente por ser muito conhecido por aquele que o percebe ou o reconhece.

A personagem presente no sonho do narrador é estranhamente familiar a ele, dada a semelhança ao seu pai, mas o deixa terrivelmente confuso e angustiado por não o reconhecer em sua totalidade. Não podendo afirmar ser seu pai ou não, o protagonista observa atônito a atitude inalterável do espectro diante das risadas enlouquecidas, da mudança na luminosidade do ambiente e da própria presença do narrador na cena.

No segundo sonho relatado, ocorre a morte da mãe do protagonista. A familiaridade com as personagens presentes na ação dá o tom realista e intimista para a situação exposta. Além de sua mãe, sua irmã, Magalí, encontra-se neste relato que também se passa na casa dos pais do protagonista. Outra vez, quando se tem a revelação do oculto que se torna estranhamente familiar, existe a mudança de coloração e luminosidade na cena, mas, dessa vez, esta transformação recai sobre a pele da mãe morrendo:

¡Sueño con la muerte de mi madre! Breve pero intensa agonía, en mis brazos. Ha caído de espaldas y se ha dado un golpe en la cabeza - estábamos hablando, un momento antes, de uno de mis viajes. Los colores de su piel cambian de pronto - eran

9 A palavra alemã 'unheimlich' é obviamente o oposto de 'heimlich' ['doméstica'], 'heimisch' ['nativo'] - o oposto do que é familiar; e somos tentados a concluir que aquilo que é 'estranho' é assustador precisamente porque não é conhecido e familiar. Naturalmente, contudo, nem tudo o que é novo e não familiar é assustador; a relação não pode ser invertida. Só podemos dizer que aquilo que é novo pode tornar-se facilmente assustador e estranho; algumas novidades são assustadoras, mas de modo algum todas elas. Algo tem de ser acrescentado ao que é novo e não familiar, para tornálo estranho. (FREUD, 1919, p.3). 
vivos, brillantes, casi eléctricos, y luego, de pronto, palidecen. Está completamente desnuda, y su piel es del color de la ceniza. Ha oscurecido toda ella. Esto ocurre en la cocina de su casa, [...]. Me inclino hasta el suelo para levantarla. En pocos segundos ha adelgazado horriblemente. Quiero llevarla a la sala. En el corredor me encuentro con Magalí, y se produce una discusión absurda acerca de dónde debemos ponerla a descansar. Decidimos llevarla a su cuarto. Yo voy hablando con ella - la llevo en brazos. Ha cerrado los ojos. Le digo $<<\mathrm{Mi}$ amor, mi amorcito > y sé que está muriendo. Al llegar al dormitorio, ha muerto. Despierto entre sollozos. (REY ROSA, 2009, p.95) ${ }^{10}$

Nesse relato, o emagrecimento repentino e drástico da personagem também é destacado assim como no primeiro sonho descrito. Ao citar que as personagens que se revelam em seus sonhos estão radicalmente mais magras, o protagonista remete à ideia de figuras cadavéricas que tomaram o lugar dos semblantes habitualmente conhecidos por ele. A desfiguração dessas personagens, que são familiares para o protagonista, causa assombro, medo e amedrontamento nele por conta das semelhanças que são percebidas nos sonhos em relação à sua realidade. A mudança corporal ocorrida na mãe do protagonista

10

Sonho com a morte de minha mãe! Breve, mas intensa agonia em meus braços. Caiu de costas e bateu a cabeça - um momento antes, estávamos conversando sobre uma de minhas viagens. As cores de sua pele mudam de repente - eram vivas, brilhantes, quase elétricas e, de repente, empalidecem. Ela está completamente nua, e sua pele é cinza. Ela toda escureceu. Isso aconteceu na cozinha de sua casa, [...]. Inclinome até o chão para levantá-la. Em poucos segundos, ela emagreceu terrivelmente. Quero levá-la para a sala. No corredor, encontro Magalí, e começamos uma discussão absurda sobre o lugar aonde devemos levá-la para descansar. Decidimos levá-la para seu quarto. Eu vou falando com ela - levo-a nos braços. Ela fechou os olhos. Digo a ela: "Meu amor, meu amorzinho", e sei que está morrendo. Ao chegar ao quarto, está morta. Acordo entre soluços. (REY ROSA 2011, p.100). 
aponta para a transfiguração na narrativa quanto àquilo que se tinha como familiar e agradável para uma situação caótica dentro de uma possibilidade estranhamente familiar. Tudo estava tranquilo, mãe e filho conversavam na cozinha tranquilamente, mas, de repente, tudo se transforma quando a mãe cai de costas e bate a cabeça.

Tanto no primeiro quanto no segundo sonho existe um elemento de partida que desencadeia as transformações nos relatos: no primeiro, são as risadas enlouquecidas que fazem o protagonista ir até o corredor onde tudo repentinamente fica escuro; no segundo, a queda da mãe desencadeia a transformação: antes, com a pele viva e brilhante, quase elétrica e, agora, com a pele cinza, a mãe escureceu completamente.

A discussão com sua irmã Magalí no sonho revela o absurdo narrado diante de uma situação angustiante ao mesmo tempo em que se reforça a atenção para o fato de tal acontecimento ser possível na realidade. De certo modo os sonhos descritos podem ser narrativas variáveis para a narrativa central do protagonista. São os diversos caminhos possíveis pelos quais o narrador poderia ter se enveredado em seu próprio relato. Misturam-se linhas narrativas que pairam sobre o real e o imaginário dentro de uma obra que perpassa o biográfico e o ficcional.

Entre esses sonhos, intercalam-se cenas sobre a investigação do narrador sobre Benedicto Tun e os documentos do Arquivo e imagens do cotidiano guatemalteco e do protagonista. Depois do primeiro sonho, o protagonista traz informações sobre a execução de trinta e seis pessoas nos últimos seis meses na região do Lago 
Atitlán, ato denominado "limpeza social" pela imprensa. Os grupos armados publicavam uma lista com o nome das próximas vítimas antes de seus ataques. Logo depois do segundo sonho, o narrador descreve a cena em que foi buscar Pía, sua filha, no catecismo e no estacionamento encontra uma dúzia de guarda-costas acompanhando algumas "mães angustiadas" buscando também seus filhos.

Inaugurando os relatos do terceiro caderno, tem-se a declaração do relator de Direitos Humanos das Nações Unidas, Philip Alston, acusando a Polícia Nacional Guatemalteca de ser a mandante e executora dos assassinatos descritos como "limpeza social" no Lago Atitlán. Segundo o narrador, Philip Alston também afirma que a Guatemala é um bom país para se cometer um crime ${ }^{11}$. Neste sentido, entende-se que, tanto nos relatos das cenas do cotidiano guatemalteco quanto nos sonhos do protagonista, tudo aquilo que deveria permanecer secreto e oculto veio à tona de alguma uma maneira. É nesse mundo onírico que os medos tomam forma.

Desse modo, a maioria das cenas relatadas, seja dos sonhos do protagonista, ou seja do cotidiano revelado, são estranhamente familiares na realidade absurda apresentada. O terceiro sonho possui as mesmas características dos relatos anteriores. Novamente na casa de seus pais, o protagonista confronta-se com uma figura familiar, mas com traços que o incomodam:

Anoche, de nuevo, pesadilla aterradora. Estaba, en el sueño, en casa de mis padres, en el dormitorio al que solíamos llamar $\ll$ del abuelito»>. Estoy despierto, pero acostado en la cama, en la oscuridad. Oigo ruidos, me levanto a investigar.

11 <Éste es un buen país para cometer un crimen. > (REY ROSA, 2009, p.101). 
Camino, sin encender luces, sigo hacia la sala y el comedor, de donde provienen los ruidos. Al entrar allí, me detengo, asustado. Un hombrecito, evidentemente un ladrón, está inclinado del otro lado de la mesa, de espaldas a mí; busca algo en un mueble que contiene cristalería. Enciendo una luz, el hombrecito se vuelve. Tiene la cara de Mark Rich, un pintor (creo que finalmente frustrado) que conocí en Marruecos y con quien luego hice amistad en Nueva York, pero de quien no he tenido noticias en más de veinte años. ¡Es él! - pienso -, pero mucho más delgado y como en miniatura. Parece que está furioso, su hocico recuerda el de un murciélago. Miro a mi alrededor, en busca de un objeto contundente para atacar o defenderme. El otro toma un gran florero de vidrio que está encima de mueble donde husmeaba, hace ademán de lanzármelo. Yo emito entonces un ruido inarticulado, medio grito, medio gemido que apenas sale de mi boca, para pedir ayuda. Despierto empapado en sudor. Me levanto para comprobar que estoy solo en el apartamento; voy a asegurarme de que la puerta de entrada tiene puesto el pasador. (REY ROSA, 2009, p.102) (2 $^{12}$

12 Ontem à noite, novamente, pesadelo terrível. No sonho, eu estou na casa de meus pais, no cômodo que costumávamos chamar de "quarto do vozinho". Estou acordado, mas deitado na cama, no escuro. Ouço ruídos e me levanto para averiguar. Caminho sem acender as luzes, sigo até a sala e a copa, de onde vêm os ruídos. Ao entrar lá, paro, assustado. Um homenzinho, evidentemente um ladrão, está inclinado do outro lado da mesa, de costas para mim; procura algo numa cristaleira. Acendo uma luz, o homenzinho se vira. Tem a cara de Mark Rich, um pintor (acho que frustrado) que conheci no Marrocos e com quem depois fiz amizade em Nova York, e de quem durante mais de vinte anos não tive notícias. É ele! - penso -, mas muito mais magro, quase uma miniatura. Parece estar furioso, seu focinho lembra o de um morcego. Olho ao redor, em busca de um objeto contundente para atacar ou me defender. O outro pega um grande vaso de vidro que está em cima do móvel no qual xeretava, faz menção de jogá-lo em mim. Eu, então, emito um ruído inarticulado, meio grito, meio gemido, que mal sai de minha boca, para pedir ajuda. Acordo encharcado de suor. Levanto-me para comprovar que estou sozinho no apartamento; vou conferir se a porta de entrada está trancada. (REY ROSA, 2011, p.108). 
Neste trecho, assim como nos sonhos anteriores, existe a figura familiar transfigurada em algo que amedronta ou assusta o protagonista dentro de um ambiente também familiar que serve para dar uma aparente tranquilidade ao narrador, mas que se revela sufocante a partir da situação trazida pelo relato. Também se encontra o jogo de luz e sombra nos três sonhos, incorporando elementos cinematográficos que reforçam a dualidade do claro e do escuro (do oculto e do revelado). Essa contraposição é acentuada da mesma forma pelos objetos que o homenzinho soturno possui próximo a ele: uma cristaleira em que mexia quando o protagonista chegou à sala e um vaso de vidro grande pego para ser jogado contra o narrador.

Neste pesadelo, o acender das luzes também revela a figura oculta que causa temor no protagonista. Terrivelmente magro, como as outras imagens, a personagem parece estar furiosa e ter um focinho como a de um morcego, animal comumente relacionado às trevas e à escuridão. A familiaridade é construída a partir da figura do pintor conhecido pelo narrador em Marrocos ao passo que o estranhamento é ponderado com a informação de que o protagonista não o vê há mais de duas décadas juntamente com a magreza notável e o rosto do mamífero de hábitos noturnos.

O ruído inarticulado para pedir ajuda reforça a angústia dentro do relato do sonho remetendo a um aprisionamento, à situação ou à impossibilidade de tentar defender frente ao exposto. O encharcar das roupas pelo suor e o acordar em soluços refletem a intensidade e o desespero trazido pelos sonhos tidos pelo protagonista. No último, a experiência revela-se tão próxima da realidade que o narrador levanta da cama e imediatamente vai conferir o trancamento da 
porta de seu apartamento. Essa sensação do real misturado com o irreal é o que permeia todo o romance e também é a matéria que forma os sonhos do protagonista.

As descrições dos pesadelos que o protagonista tem durante as noites reforçam um tom desesperador e agonizante na narrativa que acabam se transformando em uma agressividade da própria escrita. Os questionamentos feitos, os pensamentos filosóficos expostos e discutidos e as dúvidas da condição humana se transformam, dessa maneira, em uma agressividade, escrita e conceitual.

As características de um ambiente insólito permanecem durante toda a narrativa, entre as indagações e questionamentos do narrador, entre os relatos de violência estatal e cotidiana, reforçando-se em seus sonhos e em detalhes apresentados após tais relatos. Um dos sonhos mais longos relatado pelo protagonista se dá no quinto caderno após descobrir seu apelido no Arquivo. Em uma segunda-feira, relata ter sido perseguido por policiais durante um sonho. Na narrativa, quem comanda a perseguição policial contra ele é uma personagem muito semelhante a Benedicto Tun, antigo diretor do Gabinete de Identificação. O protagonista tem o prazo de um mês para deixar o país e vê esse tempo se esgotando sendo, então, aconselhado por seu pai e por um advogado a fugir. Quando relata a perseguição dos policiais, o narrador diz se esconder em uma casa circular de teto cônico com vários andares:

Unos policías me buscan en el piso inferior; yo ya estoy escondido cerca del vértice de palma. Los policías desisten y vuelven a salir. No me atrevo a moverme, aunque estoy en una posición imposible, 
con dolor en el cuello y la espalda. Después de un silencio que me parece muy largo, oigo que hay gente en el exterior. [...] (REY ROSA, 2009, p.144) ${ }^{13}$

Logo em seguida, o narrador diz que encontra sua mãe e outras mulheres pertencentes ao grupo Mães Angustiadas, associação de mulheres fundada em 1995 que busca segurança e paz para população guatemalteca. Elas afirmam que ele deve sair do país, pois ainda continuarão as buscas por ele. Depois disso, lembra-se de estar viajando por estradas que o levam a Belize e indaga-se por quanto tempo teria de ficar longe de sua filha Pía.

O intrigante na narrativa fica por parte do relato do narrador feito após dois dias desse sonho. Neste relato, o protagonista conta que construiu mais "blocos Barceló" com sua filha, andou a cavalo e nadou na piscina. Além disso, conta que não viu B+ no dia anterior e que ela havia mandado uma mensagem reclamando da presunção terrível do narrador. Depois, ele faz a seguinte afirmação, separada em uma linha única dos demais parágrafos com relatos de seu cotidiano: Intenso dolor lumbar. (REY ROSA, 2009, p.145) ${ }^{14}$.

Este comentário poderia ser considerado sem importância caso não se tivesse a informação anterior de que, em seu sonho, há dois dias, o narrador tivesse ficado em uma posição incômoda que o deixa com dor no pescoço e nas costas. Assim como o Arquivo de La Isla que se assemelha a um labirinto pelas suas características, assim como seu apelido no Arquivo é Matrix, que numa posição impossível, com dor no pescoço e nas costas. Depois de um silêncio que me parece muito longo, noto que há pessoas lá fora. [...] (REY ROSA, 2011, p.152).

14 Intensa dor lombar. (REY ROSA, 2011, p.153). 
questiona a realidade existente, seus relatos de sonhos permeiam os acontecimentos do cotidiano narrado pelo protagonista.

Pensando nesta característica do insólito, no fantástico contemporâneo, o homem é o fim de tudo e não mais instrumento. Não há mais a ideia de um elemento fantástico inserido no mundo natural senão um homem que se sente estrangeiro em seu próprio mundo (SARTRE, 2005). Deste modo, a concepção da realidade é posta em xeque porque os elementos insólitos se apresentam como verdade dentro de uma esfera de possibilidades verossímeis, apesar de que essa esfera de verdade não seja válida se confrontada com as experiências contraditórias consideradas reais no mundo natural humano. Segundo Campra (2001, p.168):

en la literatura fantástica el desfase se crea a partir de otros parámetros: todo está en la experiencia, y todo es presentado como verdad, pero las verdades son discrepantes. Así, se pueden tener muchas definiciones diferentes de la realidad: por parte del personaje (protagonista o testigo); por parte del narrador; por parte del destinatario (en cuanto presencia explícita o implícita en el texto). ${ }^{15}$

Assim, encontram-se diversas possibilidades da confirmação de um acontecimento fantástico, independente de uma hesitação por conta da interpretação do leitor quanto à existência ou não de um elemento sobrenatural e sua importância para a narrativa. Entendem-se as possíveis relações existentes entre o real textual e o real extratextual como elementos pertencentes tanto à esfera

15 na literatura fantástica a defasagem é criada a partir de outros parâmetros: tudo está na experiência, e tudo é apresentado como verdade, mas as verdades são discrepantes. Assim, pode-se ter muitas definições diferentes da realidade: por parte da personagem (protagonista ou testemunha); por parte do narrador; por parte do destinatário (enquanto presença explícita ou implícita no texto). (Tradução nossa). 
fantástica como àquela considerada realista. Instaura-se o insólito pela linguagem presente na narrativa e não na dependência da interpretação da leitura do texto ou ainda pela necessidade de uma configuração de narrativa fantástica em que a presença do monstruoso se instaure como ameaça externa. Neste aspecto, o monstruoso está plenamente inserido no cotidiano, e a forma de narrar este encontro com o real monstruoso é bastante singular em Rey Rosa.

A descrição da dor lombar do protagonista no seu relato cotidiano faz o leitor questionar a possibilidade de uma realidade sem influência de um universo insólito, pois os elementos encontrados nos dois ambientes reforçam o emaranhamento desses dois mundos. É o que acontece no conto La señal, publicado em 1985 no livro El cuchillo del mendigo.

Em um conto de uma página, o narrador revela sua busca para descobrir por que, depois de ter visitado a cidade misteriosa T., aparecem em seu rosto arranhões constrangedores. Ele sempre tenta lembrar-se se, pela noite, ele mesmo poderia ter feito tais marcas, mas, por mais que revire suas memórias, não consegue se recordar de nada estranho. Seus questionamentos sem respostas e a frequência dos arranhões idênticos em sua face fazem com que ele peça ajuda a um amigo, solicitando que este lhe vigie o sono para ver o que acontece quando o narrador dorme. Aceitando de bom grado, o amigo vigia o sono do protagonista por nove noites seguidas, nas quais nenhuma marca é encontrada. Ambos acreditam que nada de extraordinário aconteceu e desistem da vigília. Entretanto, na noite seguinte ao término da observação, surge uma nova marca no rosto do homem. 
Após tentativas frustradas de descobrir o que acontecia, ele afirma que pegou uma série de livros e empilhou-os a fim de colocar sobre ele o espelho do banheiro, possibilitando uma vista inteira de seu corpo enquanto dormisse deitado na cama do hotel. Para conseguir desvendar o mistério das marcas, ele coloca em seus olhos duas pinças que the permitem dormir de olhos abertos de modo que pudesse se ver pelo espelho em cima da pilha. Quando, no sonho, eclode algo sem forma definida e lhe ocasiona o arranhão, ele desperta assustado e procura acalmar-se para afastar a ideia absurda proveniente do sonho. Entretanto, nenhuma outra solução plausível é apresentada e, dois dias depois, a marca reaparece em seu rosto, criando a ideia de que o mistério permanece ou por ele não aceitar a resposta do insólito ou por não realmente ter descoberto a chave de seu enigma.

Em El material humano (2009), não existe um questionamento sobre a dor nas costas do protagonista nem uma não aceitação sobre a possibilidade de isso ser proveniente do que ocorreu no sonho por parte dele ou de qualquer outra personagem. Entretanto, o que se percebe é que o narrador deixa essa indagação para o leitor, destacando a frase em relação às demais e para ser possível fazer a relação com o relato do sonho apresentado anteriormente.

Dessa maneira, entende-se que, em El material humano (2009), Rey Rosa apresenta uma estética que conecta elementos ficcionais e históricos à violência estrutural, léxica e também cotidiana e a mecanismos que apresentam o insólito a partir do absurdo dos fatos narrados. É uma tentativa de compreender a realidade que se faz presente e que se mostra diante de todos como inimaginável. Cada relato exposto apresenta-se trançado 
com um dos elementos citados de alguma forma, seja pela estrutura revelada seja pelas indagações levantadas pelo narrador ou suscitadas no leitor pela incapacidade de acreditar facilmente nas diversas situações mostradas e seus desfechos que fogem, muitas vezes, da compreensão do real.

\section{CONSIDERAÇÕES FINAIS}

Em El Material Humano (2009), tem-se um jogo com fatos históricos e o processo de escrita em que a violência se faz presente pelos dois vieses apresentados, questionando sempre a viabilidade de uma obra ficcional e sua aproximação com a realidade. Dessa forma, a constante ameaça, o perigo, o insólito e o absurdo caminham juntos e arquitetam esta narrativa.

A maneira como o autor aborda e utiliza a violência em seus textos é a grande chave para o seu projeto estético. Além da violência evidente, a postura de Rey Rosa ao elaborar seu narrador contribui para a uma aproximação entre a realidade e a ficção e possibilita os questionamentos daquilo que se pode ser considerado real ou não. As proposições feitas no romance, em que se tem um narrador protagonista, juntamente com as indagações filosóficas e o jogo narrativo construído com a proposta de se pôr sempre em dúvida o que pode ser ficcional ou não, são algumas das características dessa e de outras obras do autor.

Essa é a proposta de Rey Rosa que, em muitos momentos, deixa o leitor fazer suas próprias conclusões dos fatos narrados e avaliálos conforme seu crivo e dá a possibilidade ao leitor de preencher as lacunas deixadas intencionalmente no texto para que estas o motivem a refletir sobre aquilo que está sendo proposto. 
Compondo a estética do autor, não apenas neste romance, mas em outros, está a presença do insólito, do absurdo, da superstição e do místico que servem como ferramentas para criar um universo em que o leitor percebe uma violência e experimenta a instabilidade causada dentro do mundo concreto a partir da naturalização de ações e estruturas textuais e linguísticas violentas em uma realidade traumática apresentada sem pudor.

\section{REFERÊNCIAS}

CAMPRA, Rosalba (2001). "Lo Fantástico: una isotopía de la transgresión". In: ROAS, David. (Org.). Teorías de lo fantástico. Madrid: Arco Libros, p.153-191. (2008). "Los desafíos del silencio". In: Territorios de la ficción: lo fantástico. Sevilla: Editorial Renacimiento, p.120-150.

CANO, Luis (2012). "Cárcel de Árboles, de Rodrigo Rey Rosa, y la meta-cienciaficción". Revista Iberoamericana, 238-239; 389-406.

FREUD, Sigmund (1969). "O estranho". In: História de uma neurose infantil. E.S.B., vol.XVII, Rio de Janeiro: Imago.

GUTIÉRREZ, Emiliano Coello (2008). "La narrativa breve de Rodrigo Rey Rosa: un vuelco a la racionalidad". Pensamiento Actual, 8, 54-59.

REY ROSA, Rodrigo (2009). El material humano. Barcelona: Anagrama. (2011). O Material Humano. Josely Vianna Baptista (Trad.). São Paulo: Saraiva. (2014). 1986.Cuentos Completos. Barcelona: Alfaguara.

SARTRE, Jean Paul (2005). Situações l: críticas literárias. São Paulo: Cosac Naify. 